\title{
Complex carbohydrate digestion and large bowel fermentation in rats given wholemeal bread and cooked haricot beans (Phaseolus vulgaris) fed in mixed diets
}

\author{
BY FIONA B. KEY* AND J. C. MATHERS $\dagger$ \\ Department of Biological and Nutritional Sciences, University of Newcastle upon Tyne, \\ Newcastle upon Tyne NE1 $7 R U$
}

(Received 4 November 1991 - Accepted 25 March 1992)

\begin{abstract}
The digestion of non-starch polysaccharides (NSP) and of resistant starch (RS) by rats fed on wholemeal-bread-based diets containing $0-450 \mathrm{~g}$ cooked, freeze-dried haricot beans (Phaseolus vulgaris)/kg diet was measured over the final $14 \mathrm{~d}$ of a $21 \mathrm{~d}$ feeding experiment. The bread and beans provided all the dietary polysaccharide. RS could not be detected consistently in faeces and it was assumed that this fraction was entirely fermented in the large bowel (LB). NSP digestibilities were 0.56 and 0.86 for wholemeal bread and beans respectively with no evidence that the dietary presence of beans affected digestibility of bread NSP. Bean non-cellulosic polysaccharides were highly digestible with values of $0.98,0.88$ and 0.99 for arabinose, xylose and uronic acids components respectively. There were large increases in organic matter flow to the LB when beans were fed which was associated with marked caecal hypertrophy and alterations in caecal volatile fatty acids (VFA) pattern. Calculated VFA absorption from the LB was 5-fold higher with the highest level of beans and this was reflected in higher concentrations of VFA in portal and heart blood.
\end{abstract}

Wholemeal bread: Haricot beans: Complex carbohydrates: Large bowel fermentation: Rat

Mature haricot beans (Phaseolus vulgaris seeds) are common human foods. In North America and Western Europe, small-seeded white varieties are processed commercially and consumed as canned baked beans (Tobin \& Carpenter, 1978) with average UK consumption being $18 \mathrm{~g}$ /head per d (National Food Survey Committee, 1990). Haricot beans are low in fat (approximately $18 \mathrm{~g} / \mathrm{kg}$ dry matter (DM)) but rich in complex carbohydrates (Paul \& Southgate, 1978; Tobin \& Carpenter, 1978; Reddy et al. 1984), appear to have hypocholesterolaemic effects in man (Shutler et al. 1987a, b, 1989) and are, therefore, a potentially valuable component in the UK diet (Department of Health and Social Security, 1984). Beans are frequently eaten together with cereals and, whilst the protein quality of such mixtures has been studied intensively (for review, see Tobin \& Carpenter, 1978), there is little information on the digestion of their complex carbohydrates despite the fact that this fraction accounts for approximately 0.77 and 0.85 of the dry matter (DM) in beans and cereals respectively (Paul \& Southgate, 1978). It is now well established that isolated complex carbohydrates (Englyst et al. 1987; Tulung et al. 1987) or foods rich in non-starch polysaccharides (NSP) (Cheng et al. 1987; Goodlad \& Mathers 1990; Mathers et al. 1990) have marked effects on rat large bowel (LB) fermentation, but there is little information on the effects of mixed diets which are more relevant to man.

The present experiment was designed to quantify the digestion by rats of complex

*Present address: MRC Institute of Hearing Research, University of Nottingham, University Park, Nottingham.

$\dagger$ For reprints. 
carbohydrates, in particular starch resistant to $\alpha$-amylase (EC 3.2.1.1) (resistant starch; RS) and the NSP fraction in mixed diets containing wholemeal bread and cooked haricot beans. Multiple linear regression (MLR) techniques were used to obtain separate estimates of digestibility for wholemeal bread and for beans and also to test the hypothesis that the dietary presence of haricot beans altered the digestibility of bread NSP. The proportion of wholemeal bread in the diet was held constant whilst the contribution of beans increased from 0 to $450 \mathrm{~g} / \mathrm{kg}$ to enable investigation of the capacity of the rat LB to ferment the increased amount of substrate supplied to that organ. Measurements were also made of the amount of organic matter (OM) fermented in the LB and of the caecal volatile fatty acid (VFA) pattern from which estimates of VFA absorption were derived.

Brief accounts of parts of the present study have been presented (Key \& Mathers, 1989, 1990).

\section{MATERIALS AND METHODS}

\section{Animals and housing}

Twenty-four male Wistar rats were purchased (A. Tuck \& Sons, Battlesbridge, Essex) and housed in individual Perspex and stainless steel metabolism cages (Thompson, 1970) which permitted complete separation and collection of urine and faeces.

\section{Diets and feeding}

Four diets were formulated (Table 1) each containing an equal concentration of wholemeal bread ( $500 \mathrm{~g} / \mathrm{kg}$ air-dry matter) and with graded concentrations of cooked haricot beans. The bread was purchased as $800 \mathrm{~g}$ sliced loaves from Robertsons Bakers, Carlisle, Cumbria, cut into approximately $20 \mathrm{~mm}$ squares, frozen at $-20^{\circ}$ within $4 \mathrm{~h}$ of delivery and then freeze-dried. The haricot beans were cooked in an autoclave (Astell Heason 2000 series) set at 10 psi for $10 \mathrm{~min}$ which gave a total cooking time at $>100^{\circ}$ of approximately $30 \mathrm{~min}$. The beans were drained, frozen at $-20^{\circ}$ and freeze-dried. Both bread and beans were milled to pass a $1 \mathrm{~mm}$ screen and stored at $-20^{\circ}$ until incorporated into the diets. The diets were designed to be isonitrogenous based on the Paul \& Southgate (1978) food tables. All diets contained $2 \mathrm{~g} \mathrm{Cr}_{2} \mathrm{O}_{3} / \mathrm{kg}$ as an indigestible marker to enable estimation of digesta flow rates, especially at the terminal ileum, and of caecal transit times (TT) (Goodlad \& Mathers, 1990).

Animals were offered $20 \mathrm{~g}$ air-dry diet at 10.00 hours daily with uneaten food removed at the same time the following morning. Water was available ad lib.

\section{Experimental protocol}

The rats, initial weight 249 (SE 2.6) g, were weighed every $7 \mathrm{~d}$. After $7 \mathrm{~d}$ adaptation to the diets there followed two consecutive $7 \mathrm{~d}$ balance periods with total collection of faeces and urine and measurement of intake. At the end of this period the animals were injected intraperitoneally with vincristine sulphate $(1 \mathrm{mg} / \mathrm{kg}$ body weight provided in sterile saline $(9 \mathrm{~g} \mathrm{NaCl} / 1)$ containing $0.5 \mathrm{mg}$ vincristine sulphate $/ \mathrm{ml}$ ). After $2 \mathrm{~h}$ each animal was anaesthetized with diethyl ether, and blood, digesta and tissue samples collected as described by Goodlad \& Mathers (1990). In addition, samples of duodenal, caecal and colonic tissue were taken for histological and enzymological measurements which will be reported separately.

\section{Analytical methods}

NSP and its constituents were determined as described by Englyst \& Cummings (1984) and RS by omitting the dimethyl sulphoxide (DMSO) addition step. This fraction is probably mainly retrograded amylose $\left(\mathrm{RS}_{3}\right.$; Englyst \& Kingman, 1990) and may not represent all the 
Table 1. Formulation $(\mathrm{g} / \mathrm{kg})$ and analysed composition $(\mathrm{g} / \mathrm{kg}$ dry matter $(D M))$ of diets

\begin{tabular}{|c|c|c|c|c|}
\hline Diet... & $\mathrm{BHI}$ & $\mathrm{BH} 2$ & $\mathrm{BH} 3$ & $\mathrm{BH} 4$ \\
\hline Wholemeal bread* & 500 & 500 & 500 & 500 \\
\hline Haricot beans $\dagger$ (Phaseolus vulgaris) & 0 & 150 & 300 & 450 \\
\hline Sucrose & 348 & 233 & 117 & 0 \\
\hline Casein + methionine + & 99 & 66 & 33 & $2 \S$ \\
\hline Vitamin and mineral mix $\|$ & 26 & 26 & 26 & 26 \\
\hline Maize oil & 27 & 25 & 24 & 22 \\
\hline \multicolumn{5}{|l|}{ Analysed composition (g/kg DM) } \\
\hline Nitrogen & $26 \cdot 4$ & $26 \cdot 4$ & $29 \cdot 3$ & 29.6 \\
\hline Total NSP & $33 \cdot 1$ & $59 \cdot 9$ & $75 \cdot 8$ & 107.5 \\
\hline NCP & $27 \cdot 9$ & $51 \cdot 8$ & $68 \cdot 9$ & $96 \cdot 6$ \\
\hline Cellulose & $5 \cdot 3$ & $8 \cdot 1$ & 6.9 & $10 \cdot 9$ \\
\hline Arabinose & 8.9 & $16 \cdot 3$ & $23 \cdot 3$ & $28 \cdot 8$ \\
\hline Xylose & $12 \cdot 0$ & $15 \cdot 4$ & $15 \cdot 3$ & 21.9 \\
\hline Mannose & 0.3 & $0 \cdot 7$ & 0.5 & 1.5 \\
\hline Galactose & 0.8 & $2 \cdot 4$ & $3 \cdot 0$ & $5 \cdot 5$ \\
\hline Glucose & $9 \cdot 8$ & $19 \cdot 9$ & $25 \cdot 3$ & $38 \cdot 2$ \\
\hline Uronic acids & $1 \cdot 4$ & $5 \cdot 2$ & 8.4 & $11 \cdot 6$ \\
\hline Resistant starch & $3 \cdot 3$ & $9 \cdot 2$ & $12 \cdot 8$ & 17.8 \\
\hline
\end{tabular}

NSP, non-starch polysaccharides; NCP, non-cellulosic polysaccharides; DM, dry matter.

* Supplied by Robertsons Bakers, Carlisle, Cumbria. Freeze-dried and ground to pass a $1 \mathrm{~mm}$ screen.

$\uparrow$ Autoclaved at 10 psi for $10 \mathrm{~min}$. Total cooking time approximately $30 \mathrm{~min}$. Freeze-dried and ground to pass $1 \mathrm{~mm}$ screen.

$\ddagger$ Casein-L-methionine $(10: 5, \mathrm{w} / \mathrm{w})$

$\$$ L-methionine only.

If Contained (g/kg premix): $\mathrm{CaH}_{2} \mathrm{PO}_{4} 659, \mathrm{KCl} 131, \mathrm{MnSO}_{4} \cdot 4 \mathrm{H}_{2} \mathrm{O} 5 \cdot 4, \mathrm{FeSO}_{4} \cdot 7 \mathrm{H}_{2} \mathrm{O} 6 \cdot 7, \mathrm{ZnCl}_{2} .7 \mathrm{H}_{2} \mathrm{O} 2$, choline chloride 52, and (mg/kg premix): $\mathrm{CuCl}_{2}, 2 \mathrm{H}_{2} \mathrm{O} 310, \mathrm{KIO}_{3} 10$, Rovimix $\mathrm{AD}_{3}$ (Roche) 385, Rovimix E50 (Roche) 2310, menadione 19, folic acid 32, calcium pantothenate 127, riboflavin 96, thiamin hydrochloride 85 , niacin 231 , cyanocobalamin 1.9 plus sucrose to make $1 \mathrm{~kg}$.

RS in the foods. Dietary, faecal and urinary $\mathrm{N}$ were measured by a Kjeldahl procedure, $\mathrm{Cr}_{2} \mathrm{O}_{3}$ and VFA in caecal digesta as described by Mathers et al. (1990), OM by heating at $500^{\circ}$ for $16 \mathrm{~h}$, and 3-hydroxybutyrate (3OHB) in deproteinized blood enzymically (Lloyd et al. 1978). Concentrations of VFA in portal and heart blood were determined as described by Goodlad \& Mathers (1990).

\section{Experimental design, calculations and statistical analysis}

The experiment was designed as a single factor study with four treatments (diets) and six replicates (rats) per diet. Values were examined by one-way analysis of variance and orthogonal polynomials were used to describe responses to the inclusion of beans in the diets. Results are presented as means for each diet with their standard errors based on between-animals within-diets variation with $20 \mathrm{df}$. Separate estimates of apparent digestibility of polysaccharides of wholemeal bread and of haricot beans were obtained by an MLR technique (Zar, 1974) first outlined by Key \& Mathers (1990). In the present study, two MLR models were used:

$$
\text { MLR model 1: } Y=\alpha_{1} X_{1}+\alpha_{2} X_{2}+\alpha_{3} X_{1} X_{3},
$$

where $Y$ was output of NSP in the faeces, $X_{1}$ and $X_{2}$ were intakes of NSP from wholemeal bread and beans respectively, $X_{3}$ has the value of 0 or 1 when beans were absent from or present in the diet respectively, $\alpha_{1}$ and $\alpha_{2}$ are the coefficients of indigestibilities for NSP in 
bread and beans respectively and $\alpha_{3}$ is the additional effect of presence of beans on bread NSP indigestibility. Where $\alpha_{3}$ is not significant, a simpler model is appropriate:

MLR model 2: $Y=\beta_{1} X_{1}+\beta_{2} X_{2}$,

where $\beta_{1}$ and $\beta_{2}$ are the coefficients of indigestibility for bread and beans respectively. Computations were carried out using the Statgraphics package (STSC Inc., Rockville, Maryland, USA). Apparent digestibilities were calculated by subtracting the appropriate coefficients of indigestibility from unity.

Digesta flow rates and caecal TT were estimated by classical marker-ratio techniques (Faichney, 1975) as described by Goodlad \& Mathers (1990); for further discussion of the robustness of this methodology, see Mathers \& Dawson (1991). The rate of flow of a digesta component past a given point in the intestine was calculated as the rate of intake of marker $\left(\mathrm{Cr}_{2} \mathrm{O}_{3}\right)$ divided by marker: component in digesta collected from that sampling point. Caecal TT was calculated as the amount of $\mathrm{Cr}_{2} \mathrm{O}_{3}$ recovered in that organ divided by $\mathrm{Cr}_{2} \mathrm{O}_{3}$ intake rate.

\section{RESULTS}

\section{Diet composition}

Including haricot beans in the diet at the expense of sucrose and casein resulted in substantial increases in dietary NSP concentration, largely as non-cellulosic polysaccharides (NCP) and, in particular, polymers containing arabinose, xylose, glucose and uronic acids. Cellulose contributed 0.16 of the NSP in the basal (without beans) diet and 0.10 in the diet containing the highest level of beans (BH4). Mannose and galactose were minor contributors in all diets. There was also a 5 -fold increase in RS; probably mainly $\mathrm{RS}_{3}$.

\section{Food intake and growth}

Over the 2 weeks of the balance period there was a small but significant increase in DM intake (mean intakes $(\mathrm{g} / 7 \mathrm{~d}$ ) were 121 and 127 (SE $1 \cdot 1$ ) for weeks 1 and 2 respectively) but no significant differences between diets (Table 2). The rats grew equally well on all diets. $\mathrm{N}$ intakes were higher with the diets containing higher levels of beans (BH3 and $\mathrm{BH} 4$ ) because of the higher $\mathrm{N}$ contents of these diets (Table 1). Faecal $\mathrm{N}$ output increased linearly with each increment of beans in the diet and was almost twice as great with diet BH4 ( $450 \mathrm{~g}$ beans $/ \mathrm{kg}$ diet) than with the basal (without beans) diet. $\mathrm{N}$ retention was fairly similar for all diets.

\section{Gastrointestinal measurements}

Small intestine (SI) length tended to increase with increasing proportion of haricot beans in the diet but the effect was not statistically significant (Table 3). Adding beans to the diet resulted in heavier caecums with significantly greater weights of both tissue and digesta contents. Both caecal and colonic digesta contained significantly higher proportions of water (less DM per unit digesta) with the diets containing higher levels of beans. Caecal TT was not significantly affected by diet with a mean TT of 0.51 (SEM 0.04) d (Table 3), although TT for the diets containing beans (mean $0.47 \mathrm{~d}$ ) tended to be lower than that $(0 \cdot 62 \mathrm{~d})$ for the basal diet.

Each addition of beans to the diet was accompanied by very highly significant $(P<$ 0.001 ) linear increases in the amounts of DM and OM flowing from the terminal ileum to the caecum (Table 4). There were corresponding, but much smaller, increases in faecal outputs of DM and OM so that the amounts of DM and OM disappearing within the LB increased markedly with increasing proportion of beans in the diet. The amount of OM apparently fermented in the LB increased 5-fold. The proportion of ileal OM flow which 
Table 2. Dry matter (DM) intake, growth rate, food conversion ratio (FCR; $g$ food/g gain) and aspects of nitrogen metabolism in rats given wholemeal bread-based diets containing graded concentrations of cooked haricot beans (Phaseolus vulgaris)

(Means for six rats per diet; each value is based on two consecutive $7 \mathrm{~d}$ balance periods)

\begin{tabular}{|c|c|c|c|c|c|c|c|c|}
\hline \multirow{2}{*}{$\begin{array}{l}\text { Diet } \dagger \ldots \\
\text { Bean content of diet }(\mathrm{g} / \mathrm{kg}) \ldots\end{array}$} & \multirow{2}{*}{$\begin{array}{c}\mathrm{BH} 1 \\
0\end{array}$} & \multirow{2}{*}{$\begin{array}{c}\mathrm{BH} 2 \\
150\end{array}$} & \multirow{2}{*}{$\begin{array}{c}\mathrm{BH} 3 \\
300\end{array}$} & \multirow{2}{*}{$\begin{array}{c}\text { BH4 } \\
450\end{array}$} & \multirow[b]{2}{*}{ SEM } & \multicolumn{3}{|c|}{$\begin{array}{c}\text { Statistical } \\
\text { significance of } \\
\text { dietary effects }\end{array}$} \\
\hline & & & & & & Lin & Quad & Dev \\
\hline DM intake $(g / 7 d)$ & 124 & 124 & 127 & 121 & $3 \cdot 0$ & NS & NS & NS \\
\hline Growth rate $(\mathrm{g} / 7 \mathrm{~d})$ & 32 & 34 & 33 & 31 & $2 \cdot 5$ & NS & NS & NS \\
\hline FCR & $4 \cdot 0$ & 3.8 & $4 \cdot 2$ & 4.1 & $0-30$ & NS & NS & NS \\
\hline $\mathrm{N}$ intake $(\mathrm{g} / 7 \mathrm{~d})$ & $3 \cdot 28$ & $3 \cdot 26$ & 3.73 & $3 \cdot 59$ & 0.083 & $* *$ & NS & $* *$ \\
\hline Faecal $N$ output $(\mathrm{g} / 7 \mathrm{~d})$ & 0.44 & 0.53 & 0.71 & $0 \cdot 84$ & $0 \cdot 086$ & $* * *$ & NS & NS \\
\hline Urinary $\mathrm{N}$ output $(\mathrm{g} / 7 \mathrm{~d})$ & 1.53 & 1.60 & $1 \cdot 71$ & $1 \cdot 56$ & 0.063 & NS & NS & NS \\
\hline $\mathrm{N}$ retention $(\mathrm{g} / 7 \mathrm{~d})$ & $1 \cdot 31$ & $1 \cdot 13$ & $1 \cdot 31$ & $1 \cdot 20$ & 0.064 & NS & NS & $*$ \\
\hline
\end{tabular}

Lin, Quad, Dev, linear, quadratic and deviations from linear and quadratic effects of bean content of diet respectively; $\mathrm{NS}$, not significant.

* $P<0.05, * * P<0-01, * * * P<0.001$

+ For details of diet composition, see Table 1.

Table 3. Small intestine (SI) length, caecal tissue and contents weights and transit time and proportion of dry matter $(D M)$ in colonic digesta in rats given wholemeal bread-based diets containing graded concentrations of cooked haricot beans (Phaseolus vulgaris)

(Means for six rats per diet)

\begin{tabular}{|c|c|c|c|c|c|c|c|c|}
\hline \multirow{2}{*}{$\begin{array}{l}\text { Diet } \ldots \\
\text { Bean content of diet }(\mathrm{g} / \mathrm{kg}) \text {. }\end{array}$} & \multirow{2}{*}{$\begin{array}{c}\mathrm{BH} 1 \\
0\end{array}$} & \multirow{2}{*}{$\begin{array}{c}\mathrm{BH} 2 \\
150\end{array}$} & \multirow{2}{*}{$\begin{array}{c}\text { BH3 } \\
300\end{array}$} & \multirow{2}{*}{$\begin{array}{c}\text { BH4 } \\
450\end{array}$} & \multirow[b]{2}{*}{ SEM } & \multicolumn{3}{|c|}{$\begin{array}{l}\text { Statistical } \\
\text { significance of } \\
\text { dietary effects }\end{array}$} \\
\hline & & & & & & Lin & Quad & Dev \\
\hline SI length $(\mathrm{mm})$ & 1190 & 1230 & 1200 & 1270 & 21 & NS & NS & NS \\
\hline \multicolumn{9}{|l|}{ Caecum } \\
\hline Organ mass (g) & $5 \cdot 10$ & $5 \cdot 13$ & 8.63 & 9.67 & 0.47 & $* * *$ & NS & $*$ \\
\hline Tissue $(\mathrm{g})$ & $1 \cdot 04$ & $1 \cdot 14$ & $1 \cdot 57$ & $1 \cdot 85$ & 0.056 & $* * *$ & NS & NS \\
\hline Wet contents $(\mathrm{g})$ & $4 \cdot 06$ & 3.99 & $7 \cdot 07$ & 7.82 & 0.44 & $* * *$ & NS & NS \\
\hline Digesta DM (g/g wet digesta) & $0 \cdot 19$ & $0 \cdot 18$ & $0 \cdot 17$ & $0 \cdot 16$ & $0 \cdot 004$ & $* * *$ & NS & NS \\
\hline Transit time $(\mathrm{d})$ & 0.62 & $0 \cdot 43$ & $0 \cdot 50$ & $0 \cdot 48$ & 0.08 & NS & NS & NS \\
\hline Proportion of DM in colonic contents & $0 \cdot 42$ & 0.42 & $0 \cdot 35$ & $0 \cdot 28$ & 0.029 & $* * *$ & NS & NS \\
\hline
\end{tabular}

Lin, Quad, Dev, linear, quadratic and deviations from linear and quadratic effects of bean content of diet respectively; NS, not significant.

* $P<0.05, * * P<0.01$, *** $P<0.001$.

$\dagger$ For details of diet composition, see Table 1.

was apparently fermented in the LB increased curvilinearly from 0.3 to 0.6 as beans were added to the diet (Table 4). Bean consumption resulted in a small but significant $(P<0 \cdot 01)$ linear decrease in the $\mathrm{pH}$ of the caecal contents which did not match changes in caecal total VFA concentrations. However, feeding beans was associated with altered VFA pattern, i.e. higher molar proportions of propionate but less isobutyrate and isovalerate. VFA absorption from the LB estimated from ileal to faecal OM disappearance and caecal VFA 
Table 4. Flows of dry matter and organic matter $(O M)$ to, and disappearance in, the large bowel $(L B)$ of rats given wholemeal bread-based diets containing graded concentrations of cooked haricot beans (Phaseolus vulgaris)

(Means for six rats per diet)

\begin{tabular}{|c|c|c|c|c|c|c|c|c|}
\hline \multirow{2}{*}{$\begin{array}{l}\text { Diet } \dagger \ldots \\
\text { Bean content of diet }(\mathrm{g} / \mathrm{kg}) \ldots\end{array}$} & \multirow{2}{*}{$\begin{array}{c}\mathrm{BH} 1 \\
0\end{array}$} & \multirow{2}{*}{$\begin{array}{c}\mathrm{BH} 2 \\
150\end{array}$} & \multirow{2}{*}{$\begin{array}{c}\mathrm{BH} 3 \\
300\end{array}$} & \multirow{2}{*}{$\begin{array}{c}\mathrm{BH} 4 \\
450\end{array}$} & \multirow[b]{2}{*}{ SEM } & \multicolumn{3}{|c|}{$\begin{array}{c}\text { Statistical } \\
\text { significance of } \\
\text { dietary effects }\end{array}$} \\
\hline & & & & & & Lin & Quad & Dev \\
\hline \multicolumn{9}{|l|}{ Dry matter } \\
\hline Ileal flow $(\mathrm{g} / \mathrm{d})$ & $2 \cdot 5$ & $3 \cdot 9$ & $5 \cdot 4$ & $6 \cdot 3$ & $0 \cdot 22$ & $* * *$ & NS & NS \\
\hline Faecal output $(\mathrm{g} / \mathrm{d})$ & $1 \cdot 4$ & $1 \cdot 6$ & $2 \cdot 0$ & $2 \cdot 4$ & 0.06 & $* * *$ & NS & NS \\
\hline LB disappearance $(\mathrm{g} / \mathrm{d})$ & $1 \cdot 2$ & $2 \cdot 2$ & $3 \cdot 3$ & $3 \cdot 9$ & $0 \cdot 20$ & $* * *$ & NS & NS \\
\hline \multicolumn{9}{|l|}{ Organic matter } \\
\hline lleal fow $(\mathrm{g} / \mathrm{d})$ & $1 \cdot 6$ & $2 \cdot 6$ & 3.6 & $4 \cdot 5$ & $0 \cdot 14$ & $* * *$ & NS & NS \\
\hline Faecal output $(\mathrm{g} / \mathrm{d})$ & $1 \cdot 1$ & $1 \cdot 3$ & $1 \cdot 7$ & 1.9 & 0.05 & $* * *$ & NS & NS \\
\hline LB disappearance $(\mathrm{g} / \mathrm{d})$ & $0 \cdot 5$ & $1 \cdot 2$ & 1.9 & $2 \cdot 6$ & $0 \cdot 13$ & $* * *$ & NS & NS \\
\hline LB disappearance (g/g ileal OM flow) & $0 \cdot 3$ & $0 \cdot 5$ & 0.5 & 0.6 & 0.02 & $* * *$ & $* *$ & NS \\
\hline
\end{tabular}

Lin, Quad, Dev, linear, quadratic and deviations from linear and quadratic effects of bean content of diet respectively; NS, not significant.

** $P<0.01, * * * P<0.001$.

$\uparrow$ For details of diet composition, see Table 1.

molar proportions showed very highly significant linear increases over a 5-fold range as bean consumption increased (Table 5).

\section{$V F A$ and $3 O H B$ in portal and heart blood}

Whilst portal blood acetate concentration tended to increase with increased dietary inclusion of beans the increase was not statistically significant (Table 6). Linear increases in propionate, butyrate and total VFA were, however, highly significant. In heart blood there were also significant linear increases in acetate $(P<0.05)$ and propionate $(P<0.001)$ concentrations, the latter increasing from undetectable levels with the basal diet (without beans) to $24 \mu \mathrm{M}$ (diet $\mathrm{BH} 4$ ). With all diets propionate contributed less than $2 \%$ of the VFA detected in blood drawn from the heart. $3 \mathrm{OHB}$ was always higher in portal than in heart blood but was not significantly affected by diet.

\section{Digestibility of complex carbohydrates}

Although including beans in the diet in place of sucrose and casein resulted in increases in dietary NSP concentration of up to 3-fold (Table 1), there were much smaller increases (less than 2-fold) in faecal NSP output (Table 7). However, with the exception of arabinose, where no significant dietary effect was detected, faecal output of all NSP components increased strongly linearly. The measurement of RS in faeces was associated with a large coefficient of variation and faecal RS output was not significantly different from zero for all diets.

The use of MLR procedures allowed the calculation of separate estimates of apparent digestibility for NSP of wholemeal bread and cooked haricot beans and also tested the possibility that the presence of beans might influence the apparent digestibility of bread NSP with the extent of this influence estimated as the parameter, $\alpha_{3}$. MLR analysis (model 1) showed that the presence of beans had little effect on the digestibility of NSP or any of 
Table 5. Caecal $p H$, total volatile fatty acid (VFA) concentrations, molar proportions of individual VFA and calculated absorption of VFA from the large bowel $(L B)$ of rats given wholemeal bread-based diets containing graded concentrations of cooked haricot beans (Phaseolus vulgaris)

(Means for six rats per diet)

\begin{tabular}{|c|c|c|c|c|c|c|c|c|}
\hline \multirow{2}{*}{$\begin{array}{l}\text { Diet } \uparrow \ldots \\
\text { Bean content of diet }(\mathrm{g} / \mathrm{kg}) \ldots\end{array}$} & \multirow{2}{*}{$\begin{array}{c}\mathrm{BH} 1 \\
0\end{array}$} & \multirow{2}{*}{$\begin{array}{c}\mathrm{BH} 2 \\
150\end{array}$} & \multirow{2}{*}{$\begin{array}{c}\mathrm{BH} 3 \\
300\end{array}$} & \multirow{2}{*}{$\begin{array}{c}\mathrm{BH} 4 \\
450\end{array}$} & \multirow[b]{2}{*}{ SEM } & \multicolumn{3}{|c|}{$\begin{array}{c}\text { Statistical } \\
\text { significance of } \\
\text { dietary effects }\end{array}$} \\
\hline & & & & & & Lin & Quad & Dev \\
\hline $\mathrm{pH}$ & $6 \cdot 2$ & $6 \cdot 2$ & 60 & $5 \cdot 9$ & 0.08 & $* *$ & NS & NS \\
\hline $\begin{array}{l}\text { Total VFA } \\
\text { (mmol/kg caecal contents) }\end{array}$ & 185 & 168 & 205 & 194 & $10 \cdot 3$ & NS & NS & $*$ \\
\hline \multicolumn{9}{|l|}{$\begin{array}{l}\text { Molar proportions of individual } \\
\text { VFA }(\mathrm{mmol} / \mathrm{mol})\end{array}$} \\
\hline Acetate & 659 & 635 & 652 & 658 & $9 \cdot 8$ & NS & NS & NS \\
\hline Propionate & 209 & 256 & 233 & 251 & $8 \cdot 5$ & $*$ & NS & $* *$ \\
\hline Isobutyrate & 8 & 4 & 1 & 1 & $0 \cdot 8$ & $* * *$ & $*$ & NS \\
\hline Butyrate & 98 & 81 & 92 & 70 & 7.9 & NS & NS & NS \\
\hline Isovalerate & 12 & 9 & 6 & 6 & $1 \cdot 4$ & $* * *$ & NS & NS \\
\hline Valerate & 14 & 15 & 16 & 14 & $1 \cdot 0$ & NS & NS & NS \\
\hline \multicolumn{9}{|c|}{$\begin{array}{l}\text { Calculated absorption of VFA from } \\
\text { the } \mathrm{LB}(\mathrm{mmol} / \mathrm{d}) \ddagger\end{array}$} \\
\hline Acetate & $3 \cdot 8$ & $9 \cdot 1$ & $14 \cdot 7$ & $19 \cdot 8$ & $1 \cdot 01$ & $* * *$ & NS & NS \\
\hline Propionate & $1 \cdot 2$ & $3 \cdot 7$ & $5 \cdot 2$ & $7 \cdot 5$ & 0.39 & $* * *$ & NS & NS \\
\hline Butyrate & 0.5 & $1 \cdot 2$ & $2 \cdot 0$ & $2 \cdot 1$ & $0 \cdot 80$ & $* * *$ & NS & NS \\
\hline Total & $5 \cdot 5$ & $14 \cdot 0$ & 21.9 & $29 \cdot 4$ & $1 \cdot 45$ & $* * *$ & NS & NS \\
\hline
\end{tabular}

Lin, Quad, Dev, linear, quadratic and deviations from linear and quadratic effects of bean content of diet respectively; NS, not significant.

* $P<0.05, * * P<0.01, * * * \quad P<0.001$.

+ For details of diet composition, see Table 1.

$\ddagger$ Calculated from organic matter disappearance in the large bowel (Table 4) and caecal VFA molar proportions assuming conventional anaerobic stoichiometry (Demeyer \& Van Nevel, 1975).

its components in bread ( $\alpha_{3}$, not significant; Table 8$)$ so that the simpler model 2 could provide satisfactory estimates of digestibility $\left(R^{2} 0 \cdot 86-0.99\right)$. Apparent digestibility of total NSP of wholemeal bread was 0.56 with apparent digestibilities of individual monomeric constituents ranging from -0.04 (galactose) to 0.99 (uronic acids). NSP of haricot beans were much more digestible $(0.86)$ with individual sugar constituent digestibilities ranging from 0.74 (glucose) to 0.99 (uronic acids). The apparent digestibility of cellulose was relatively low and similar for both bread $(0.22)$ and haricot beans $(0.23)$.

\section{DISCUSSION}

\section{Dietary complex carbohydrates}

Haricot beans are rich in complex carbohydrates and their inclusion in the diets varied total NSP content over a 3-fold range. In agreement with Englyst \& Cummings (1984), arabinose and glucose, the latter largely in NCP, were the major monosaccharide constituents of NSP in these beans. However, the measured concentration of RS $(67 \mathrm{~g} / \mathrm{kg} \mathrm{DM})$ in our beans was approximately nine times that reported by Englyst \& Cummings (1984). This raised RS content is probably mainly in the form of $\mathrm{RS}_{3}$ arising as a consequence of cooking and 
Table 6. Concentrations of volatile fatty acids $(V F A ; \mu \mathrm{M})$ and of 3-hydroxybutyrate $(3 O H B$; $\mu \mathrm{M})$ in whole blood from the portal vein and heart of rats given wholemeal bread-based diets containing graded concentrations of cooked haricot beans (Phaseolus vulgaris)

(Means for six rats per diet except where indicated)

\begin{tabular}{|c|c|c|c|c|c|c|c|c|}
\hline \multirow{2}{*}{$\begin{array}{l}\text { Diet } \uparrow \ldots \\
\text { Bean content of } \operatorname{diet}(\mathrm{g} / \mathrm{kg}) \ldots\end{array}$} & \multirow{2}{*}{$\begin{array}{c}\mathrm{BHI} \\
0\end{array}$} & \multirow{2}{*}{$\begin{array}{c}\mathrm{BH} 2 \\
150\end{array}$} & \multirow{2}{*}{$\begin{array}{c}\mathrm{BH} 3 \\
300\end{array}$} & \multirow{2}{*}{$\begin{array}{c}\mathrm{BH} 4 \\
450\end{array}$} & \multirow[b]{2}{*}{ SEM } & \multicolumn{3}{|c|}{$\begin{array}{c}\text { Statistical } \\
\text { significance of } \\
\text { dietary effects }\end{array}$} \\
\hline & & & & & & Lin & Quad & Dev \\
\hline \multicolumn{9}{|l|}{ Portal blood } \\
\hline Acetate & 1257 & 1316 & 1290 & 1642 & $158 \cdot 2$ & NS & NS & NS \\
\hline Propionate & 55 & 117 & 226 & 256 & $40 \cdot 5$ & $* * *$ & NS & NS \\
\hline Butyrate & 22 & 28 & 57 & 78 & $9 \cdot 6$ & $* * *$ & NS & NS \\
\hline Total & $1334 \$$ & $1461 \ddagger$ & $1573 \ddagger$ & 19768 & $136.8 \%$ & $* *$ & NS & NS \\
\hline $3 \mathrm{OHB}$ & $141 \ddagger$ & $101+$ & $143^{+}$ & $102 \|$ & $31.9+$ & NS & NS & NS \\
\hline \multicolumn{9}{|l|}{ Heart blood } \\
\hline Acetate & 1220 & 1022 & 1318 & 1970 & $269 \cdot 8$ & $*$ & NS & NS \\
\hline Propionate & 0 & 7 & 20 & 24 & $5 \cdot 6$ & $* *$ & NS & NS \\
\hline $3 \mathrm{OHB}$ & 79 & 73 & 87 & 89 & $18 \cdot 6$ & NS & NS & NS \\
\hline
\end{tabular}

Lin, Quad, Dev, linear, quadratic and deviations from linear and quadratic effects of bean content of diet respectively; NS, not significant.

* $P<0.05, * * P<0.01$, *** $P<0001$.

+ For details of diet composition, see Table 1.

$\ddagger n 5$.

$\S n 3$.

$\| n 4$.

Table 7. Faecal outputs $(\mathrm{mg} / 7 \mathrm{~d})$ of non-starch polysaccharides (NSP) and of resistant starch by rats given wholemeal bread-based diets containing graded concentrations of cooked haricot beans (Phaseolus vulgaris)

(Means for six rats per diet except where indicated)

\begin{tabular}{|c|c|c|c|c|c|c|c|c|}
\hline \multirow{2}{*}{$\begin{array}{l}\text { Diet } \uparrow \ldots \\
\text { Bean content of diet }(\mathrm{g} / \mathrm{kg})\end{array}$} & \multirow{2}{*}{$\begin{array}{c}\mathrm{BH} 1 \\
0\end{array}$} & \multirow{2}{*}{$\begin{array}{c}\mathrm{BH} 2 \\
150\end{array}$} & \multirow{2}{*}{$\begin{array}{l}\mathrm{BH} 3 \\
300_{+}^{+}\end{array}$} & \multirow{2}{*}{$\begin{array}{l}\mathrm{BH} 4 \\
450 \ddagger\end{array}$} & \multirow[b]{2}{*}{ SEM } & \multicolumn{3}{|c|}{$\begin{array}{c}\text { Statistical } \\
\text { significance of } \\
\text { dietary effects }\end{array}$} \\
\hline & & & & & & Lin & Quad & Dev \\
\hline NSP & 295 & 366 & 433 & 510 & $20 \cdot 3$ & $* * *$ & NS & NS \\
\hline NCP & 205 & 229 & 290 & 311 & $14 \cdot 1$ & $* * *$ & NS & NS \\
\hline Cellulose & 90 & 137 & 143 & 199 & $7 \cdot 8$ & $* * *$ & NS & $*$ \\
\hline Arabinose & 80 & 79 & 87 & 85 & $4 \cdot 9$ & NS & NS & NS \\
\hline Xylose & 78 & 85 & 105 & 105 & $6 \cdot 7$ & $* *$ & NS & NS \\
\hline Mannose & 3 & 3 & 4 & 7 & $0 \cdot 7$ & $* * *$ & NS & NS \\
\hline Galactose & 14 & 26 & 27 & 37 & $3 \cdot 7$ & $* * *$ & NS & NS \\
\hline Glucose & 120 & 172 & 209 & 274 & $9 \cdot 9$ & $* * *$ & NS & NS \\
\hline Uronic acids & $<1$ & 1 & 1 & 3 & $0-2$ & $* * *$ & NS & NS \\
\hline Resistant starch & $<1$ & 18 & 5 & 13 & 8.9 & NS & NS & NS \\
\hline
\end{tabular}

Lin, Quad, Dev, linear, quadratic and deviations from linear and quadratic effects of bean content of diet respectively; NS, not significant; NCP, non-cellulosic polysaccharides.

* $P<0.05, * * P<0.01, * * * P<0.001$

$\dagger$ For details of diet composition, see Table 1 .

$\ddagger n 5$. 
Table 8. Apparent digestibilities, estimated by multiple linear regression $(M L R)^{*}$, for nonstarch polysaccharides (NSP) of wholemeal bread and cooked haricot beans (Phaseolus vulgaris) when fed in mixed diets to rats

(Estimates were derived using individual values for twenty-two rats $\dagger$; values are means with their standard errors)

\begin{tabular}{|c|c|c|c|c|c|c|c|}
\hline & \multicolumn{2}{|c|}{ Wholemeal bread } & \multicolumn{2}{|c|}{ Beans } & \multicolumn{2}{|c|}{$\alpha_{3}$} & \multirow[b]{2}{*}{$R^{2}$} \\
\hline & Mean & $\mathrm{SE}$ & Mean & $\mathrm{SE}$ & Mean & $\mathrm{SE}$ & \\
\hline \multicolumn{8}{|l|}{ MLR model 1} \\
\hline NSP & 0.56 & $0 \cdot 028$ & $0 \cdot 86$ & $0 \cdot 027$ & $0 \cdot 00$ & 0.052 & $0 \cdot 99$ \\
\hline NCP & 0.64 & $0 \cdot 024$ & 0.92 & 0.025 & -0.01 & 0.045 & 0.98 \\
\hline Cellulose & $0 \cdot 16$ & 0.072 & 0.25 & $0 \cdot 054$ & -0.07 & 0.085 & 0.98 \\
\hline Arabinose & $0 \cdot 56$ & 0.026 & 0.98 & 0.025 & -0.01 & 0.051 & 0.98 \\
\hline Xylose & $0 \cdot 68$ & 0.028 & 0.92 & $0-063$ & 0.04 & 0.045 & 0.97 \\
\hline Mannose & 0.55 & 0.126 & $0 \cdot 86$ & $0 \cdot 049$ & $0 \cdot 03$ & $0 \cdot 180$ & 0.85 \\
\hline Galactose & 0.08 & 0.228 & 0.83 & 0.074 & 0.37 & 0.393 & 0.91 \\
\hline Glucose & 0.40 & 0.049 & 0.75 & 0.036 & 0.01 & 0.088 & 0.99 \\
\hline Uronic acids & 0.98 & 0.009 & 0.99 & 0.002 & -0.02 & 0.018 & 0.89 \\
\hline \multicolumn{8}{|l|}{ MLR model 2} \\
\hline NSP & 0.56 & 0.023 & $0 \cdot 86$ & $0 \cdot 017$ & & & 0.99 \\
\hline NCP & 0.64 & 0.020 & 0.92 & $0 \cdot 013$ & & & 0.99 \\
\hline Cellulose & 0.22 & 0.038 & 0.23 & 0.045 & & & 0.98 \\
\hline Arabinose & 0.56 & 0.022 & 0.98 & $0 \cdot 015$ & & & 0.98 \\
\hline Xylose & 0.67 & 0.022 & $0 \cdot 88$ & $0 \cdot 046$ & & & 0.97 \\
\hline Mannose & 0.53 & 0.088 & 0.85 & 0.039 & & & 0.86 \\
\hline Galactose & -0.04 & 0.185 & 0.78 & $0 \cdot 050$ & & & $0 \cdot 91$ \\
\hline Glucose & $0 \cdot 40$ & 0.040 & 0.74 & 0.023 & & & 0.99 \\
\hline Uronic acids & 0.99 & 0.008 & 0.99 & 0.001 & & & 0.89 \\
\hline
\end{tabular}

$\alpha_{3}$, Additional effect of presence of beans on indigestibility of NSP fraction in wholemeal bread; NCP, noncellulosic polysaccharides.

* For details of MLR models 1 and 2, see pp. 499-500.

$\ddagger$ Samples for one rat on each of diets $\mathrm{BH} 3$ and BH4 were missing.

cooling the beans since similar procedures have been reported to increase the concentration of RS in sorghum (Sorghum bicolor (L.) Moench; Bach Knudsen et al. 1988) and in peas (Pisum sativum; Goodlad \& Mathers, 1992). It should not be assumed that the RS fraction we have measured represents, necessarily, all the starch which will escape digestion in the small intestine. From in vitro studies Englyst \& Kingman (1990) reported that there was approximately twice as much physically inaccessible starch $\left(\mathrm{RS}_{1} \mathrm{cf} \mathrm{RS}_{3}\right)$ in cooked, cooled beans.

\section{Digestibility}

The increased faecal DM output accompanying increased dietary bean concentration (Table 4) was, in part, due to greater outputs of NSP (Table 7), but faecal NSP concentration was very similar for all diets $(211,222,215$ and 214 (SE 9.4) g/ $\mathrm{kg} \mathrm{DM}$ for diets $\mathrm{BH} 1, \mathrm{BH} 2, \mathrm{BH} 3$ and $\mathrm{BH} 4$ respectively) so that other components including bacterial biomass, undigested protein from endogenous and dietary sources, and mucins are likely to be important components of this non-NSP faecal DM. The strong linear decline in apparent digestibility of $\mathbf{N}$ with increasing bean intake (Table 2) is in accord with many reports of studies in rats, pigs and man (for review, see Tobin \& Carpenter, 1978). The reasons for the low protein digestibility in beans include (1) the presence of protease inhibitors (Liener \& Kakade, 1980) which can largely be overcome by thermal processing, 
(2) protein fractions which are inherently resistant to proteolytic enzymes (Tobin \& Carpenter, 1978), (3) enhanced loss of endogenous $\mathrm{N}$, possibly through stimulation of mucosal cell turnover (Skurpakkar et al. 1979) although this is disputed by FairweatherTait et al. (1983), and (4) increased output of bacterial N (Mason \& Palmer, 1973; Bender \& Mohammidiha, 1981) as a result of LB bacterial proliferation on the additional carbohydrate supplied to that organ by the beans. In these animals we found no evidence that feeding beans altered gut epithelial proliferation rate (Key \& Mathers, 1989) and suggest that the major reason for the increased faecal $\mathrm{N}$ loss was greater production of bacterial N within the LB (Goodlad \& Mathers, 1990, 1991).

MLR procedures were used to obtain separate estimates of apparent digestibility for NSP of wholemeal bread and haricot beans whilst MLR model 1 also tested for associative effects (Mitchell, 1964), i.e. the possibility that the dietary presence of beans affected the digestibility of bread NSP. There was little evidence of the latter (Table 8) as was also reported by Goodlad \& Mathers (1991) for mixtures of wheat and raw peas fed to pigs. The apparent digestibility of wholemeal bread NSP $(0 \cdot 56)$ was a little higher than those $(0.47$ and 0.53$)$ reported by Key \& Mathers (1993) for rats fed on bread from the same bakery and using the same analytical methods. For comparison, Ranhotra et al. (1988), using the enzymic-gravimetric method of Prosky et al. (1984), reported wholemeal bread NSP digestibility by rats was 0.44 whilst in man apparent digestibility of fibre in wheatbran-enriched breads were 0.44 (Van Dokkum et al. 1983, using the van Soest \& Wine (1967) method) and 0.33 (Stephen et al. 1986, determined as NSP by essentially the same method as that used in the present study). Pigs digested 0.65 of the NSP in raw wheat (Goodlad \& Mathers, 1991). The NSP of haricot beans were much more digestible ( $0 \cdot 86)$ and similar to values for raw and cooked peas (Goodlad \& Mathers, 1990, 1992) and for white bread (Key \& Mathers, 1993) fed to rats. For both bread and beans cellulose was much less digestible than the NCP, again in agreement with many studies in rats (Goodlad \& Mathers, 1990, 1992; Key \& Mathers, 1993), man (Southgate et al. 1976; Van Dokkum et al. 1983) and pigs (Goodlad \& Mathers, 1991). Arabinose-containing polymers in beans as in peas (Goodlad \& Mathers, 1990, 1991, 1992) were very highly digested, possibly because of their presence in pectin-like water-soluble branched arabinans (Wilder \& Albersheim, 1973). The other major NCP monomer, xylose, occurs in haricot beans mainly in the form of xyloglucans which appear to link cellulose fibrils with the rest of the cell wall (Wilder \& Albersheim, 1973). This close physical association with the relatively indigestible cellulose may contribute to the lower digestibility of xylose. The RS fraction measured in the diets (probably largely $\mathrm{RS}_{3}$ ) could not be detected consistently in faeces and is assumed to have been fermented in the LB (Macfarlane \& Englyst, 1986) as observed in earlier studies (Goodlad \& Mathers, 1990, 1991, 1992; Key \& Mathers, 1993).

\section{$L B$ fermentation}

Whilst feeding beans tended to increase the length of the SI (Table 3), the effect was not statistically significant $(P>0 \cdot 05)$ and the most noticeable effects were in the LB. As expected, there was a large linear increase from 1.6 to $4.5 \mathrm{~g} / \mathrm{d}$ in the flow of OM to the $\mathrm{LB}$ with increasing bean intake. The composition of ileal OM was not determined but the contribution from NSP and measured RS (assuming that these are not digested in the upper tract; Englyst \& Cummings, 1985) was approximately $0.7,1.2,1.6$ and $2.3 \mathrm{~g} / \mathrm{d}$ for diets $\mathrm{BH} 1, \mathrm{BH} 2, \mathrm{BH} 3$ and $\mathrm{BH} 4$ respectively. This indicates that other sources including oligosaccharides of the raffinose family (Reddy et al. 1984), starches (especially $\mathrm{RS}_{1}$ ) and proteins of dietary origin and endogenous materials (Cummings \& Englyst, 1987) were equally important as LB substrates. The additional OM entering the LB with the diets containing beans was much more fermentable than that flowing with the wholemeal bread 
only diet $(\mathrm{BH} 1)$, so that whilst potential substrate supply increased 2.8 times the amount of OM apparently fermented increased 5 -fold from 0.5 to $2.6 \mathrm{~g} / \mathrm{d}$. The more highlydigestible NSP and the greater RS supply (assumed to be virtually all fermented) will have contributed to this greater OM disappearance within the LB. This greater fermentative activity was associated with a reduction in caecal $\mathrm{pH}$ in the absence of a consistent increase in total VFA concentration which suggests that either the buffering capacity of caecal contents was reduced by feeding beans or that some other acidic fermentation endproduct, e.g. lactate, not measured in the present study, was produced. The molar proportions of acetate and butyrate were little affected by diet but propionate was higher with the diets containing beans. The proportion of butyrate with the basal diet $(\mathrm{BH} 1)$ was considerably lower than that observed in earlier bread-feeding experiments (Key \& Mathers, 1993) and did not increase with increasing intake of complex carbohydrates. We have argued (Mathers \& Dawson, 1991) that whilst substrate supply can have marked effects on the pattern of fermentation endproducts (Englyst et al. 1987; Goodlad \& Mathers, 1988) other environmental factors including $\mathrm{pH}$ and TT are also important, and that reduction in caecal TT may be particularly important in increasing the proportion of butyrate. In support of this suggestion there is the observation that diet had no significant effect on caecal TT in the present study. The highly significant reductions in isobutyrate and isovalerate indicate that the balance between their production from amino acid catabolism and their use for de novo synthesis (Russell \& Hespell, 1981) shifted towards the latter in animals fed on beans.

The greater OM fermentation with the diets containing beans was achieved by caecal expansion with highly significant increases in the masses of both tissue and contents (Table 3). Possible mechanisms for the hypertrophy which often accompanies complex carbohydrate consumption by rats (Wyatt et al. 1988; Rémésy \& Demigné, 1989; Seal \& Mathers, 1989) have been discussed by Goodlad \& Mathers (1990) and Mathers \& Dawson (1991) but this remains an area of uncertainty. The higher water contents of caecal and especially colonic digesta observed in the present study when feeding beans are probably due to a greater content of bacteria (Stephen \& Cummings, 1980; Goodlad \& Mathers, 1990) with their associated intracellular and extracellular water.

\section{Supply of fermentation endproducts to the tissues}

The major fermentation endproducts are the VFA which are rapidly and extensively absorbed (McNeil et al. 1978; Ruppin et al. 1980). Our calculations of the amounts of VFA absorbed (based on OM disappearance from the LB and caecal VFA proportions) indicated that total VFA absorption increased 5.3 times so that with the diet with the highest level of beans (BH4), $29 \mathrm{~mol} \mathrm{VFA} / \mathrm{d}$ were absorbed which is equivalent to $35 \mathrm{~kJ}$ metabolizable energy.

This additional VFA supply was reflected in increases in portal blood VFA concentration (highly significant for propionate and butyrate) and in the concentration of acetate in heart blood. In addition propionate was detected in heart blood from rats fed on beans and rose linearly $(P<0.01)$ as intake of beans increased. This is in contrast to the study of Goodlad and Mathers (1990) where, even with the peas fed at the highest rate, propionate could not be detected in rat heart blood. In the present study, the concentrations of this metabolite were low and close to the limit of detection by the method used so that the apparent between-studies difference may be due more to variation in instrument sensitivity than to biological effects. It would appear that the efficiency of the liver in removing portalsupplied VFA was in order butyrate $>$ propionate $>$ acetate. 
F.B.K. was in receipt of an AFRC Food Research Studentship whilst this study was carried out.

\section{REFERENCES}

Bach Knudsen, K. E., Munck, L. \& Eggum, B. O. (1988). Effect of cooking, pH and polyphenol level on carbohydrate composition and nutritional quality of a sorghum (Sorghum bicolor (L.) Moench) food, ugali. British Journal of Nutrition 59, 31-47.

Bender, A. E. \& Mohammodiha, H. (1981). Low digestibility of legume nitrogen. Proceedings of the Nutrition Society 40,66A

Cheng, B.-Q., Trimble, R. P., Illman, R. J., Stone, B. A. \& Topping, D. L. (1987). Comparative effects of dietary wheat bran and its morphological components (aleurone and pericarp-seed coat) on volatile fatty acid concentrations in the rat. British Journal of Nutrition 57, 69-76.

Cummings, J. H. \& Englyst, H. N. (1987). Fermentation in the human large intestine and the available substrates. American Journal of Clinical Nutrition 45, 1243-1255.

Demeyer, D. I. \& Van Nevel, C. J. (1975). Methanogenesis, an integrated part of carbohydrate fermentation, and its control. In Digestion and Metabolism in the Ruminant, pp. 366-382 [I. W. McDonald and A. C. I. Warner, editors]. Armidale: University of New England Publishing Unit.

Department of Health and Social Security (1984). Diet and Cardiovascular Disease. Report of the Committee on Medical Aspects of Food Policy. London: H. M. Stationery Office.

Englyst, H. N. \& Cummings, J. H. (1984). Simplified method for the measurement of total non-starch polysaccharides by gas-liquid chromatography of constituent sugars as the alditol acetates. Analyst 109, 937-942.

Englyst, H. N. \& Cummings, J. H. (1985). Digestion of the polysaccharides of some cereal foods in the human small intestine. American Journal of Clinical Nutrition 42, 778-787.

Englyst, H. N., Hay, S. \& Macfarlane, G. T. (1987). Polysaccharide breakdown by mixed populations of human faecal bacteria. FEMS Microbiological Letters 45, 163-171.

Englyst, H. N. \& Kingman, S. M. (1990). Dietary fiber and resistant starch. A nutritional classification of plant polysaccharides. In Dietary Fiber, pp. 49-65 [D. Kritchevsky, C. Bonfield and J. W. Anderson, editors]. New York: Plenum Publishing Corporation.

Faichney, G. J. (1975). The use of markers to partition digestion within the gastro-intestinal tract of ruminants. In Digestion and Metabolism in the Ruminant, pp. 277-291 [I. W. McDonald and A. C. I. Warner, editors]. Armidale: University of New England Publishing Unit.

Fairweather-Tait, S. J., Gee, J. M. \& Johnson, I. T. (1983). The influence of cooked kidney beans (Phaseolus vulgaris) on intestinal cell turnover and faecal nitrogen excretion in the rat. British Journal of Nutrition 49 , $303-312$

Goodlad, J. S. \& Mathers, J. C. (1988). Effects of food carbohydrates on large intestinal fermentation in vitro. Proceedings of the Nutrition Society 47, 176A.

Goodlad, J. S. \& Mathers, J. C. (1990). Large bowel fermentation in rats given diets containing raw peas (Pisum sativum). British Journal of Nutrition 64, 569-587.

Goodlad, J. S. \& Mathers, J. C. (1991). Digestion by pigs of non-starch polysaccharides in wheat and raw peas (Pisum sativum) fed in mixed diets. British Journal of Nutrition 65, 259-270.

Goodlad, J. S. \& Mathers, J. C. (1992). Digestion of complex carbohydrates and large bowel fermentation in rats fed on raw and cooked peas (Pisum sativum). British Journal of Nutrition 67, 475488.

Key, F. B. \& Mathers, J. C. (1989). Effects on volatile fatty acid production and gut epithelial proliferation of adding haricot beans to a wholemeal bread diet. Proceedings of the Nutrition Society 48, 47A.

Key, F. B. \& Mathers, J. C. (1990). Estimation of the digestibilities of NSP for wholemeal bread and haricot beans fed in mixed diets. In Dietary Fibre: Chemical and Biological Aspects, pp. 254-258 [D. A. T. Southgate, K. Waldron, I. T, Johnson and G. R. Fenwick, editors]. Cambridge: Royal Society of Chemistry.

Key, F. B. \& Mathers, J.C. (1993). Gastrointestinal responses of rats fed on white and wholemeal breads: complex carbohydrate digestibility and the influence of dietary fat content. British Journal of Nutrition $\mathbf{6 9}$, $481-495$

Liener, I. E. \& Kakade, M. L. (1980). Protease inhibitors. In Toxic Constituents of Plant Foodstuffs. [I. E. Liener, editor]. New York: Academic Press.

Lloyd, B., Burrin, J., Smythe, P. \& Alberti, K. G. M. M. (1978). Enzymic fluorimetric continuous flow assays for blood glucose, lactate, pyruvate, alanine, glycerol and 3-hydroxybutyrate. Clinical Chemistry 34, 1724-1729.

Macfarlane, G. T. \& Englyst, H. N. (1986). Starch utilization by the human large intestinal microflora. Journal of Applied Bacteriology 60, 195-201.

McNeil, N. I., Cummings, J. H. \& James, W. P. T. (1978). SCFA absorption by the human large intestine. Gut 19, 819-822.

Mason, V. C. \& Palmer, R. (1973). The influence of bacterial activity in the alimentary canal of rats on faecal nitrogen excretion. Acta Agriculturae Scandinavica 23, 141-150.

Mathers, J. C. \& Dawson, L. D. (1991). Large bowel fermentation in rats eating processed potatoes. British Journal of Nutrition $66,313-329$.

Mathers, J. C., Fernandez, F., Hill, M. J., McCarthy, P. T., Shearer, M. J. \& Oxley, A. (1990). Dietary 
modification of potential vitamin $\mathrm{K}$ supply from enteric bacterial menaquinones in rats. British Journal of Nutrition 63, 639-652.

Mitchell, H. H. (1964). Comparative Nutrition of Man and Domestic Animals. New York: Academic Press.

National Food Survey Committee (1990). Household Food Consumption and Expenditure 1989. London: H. M. Stationery Office.

Paul, A. A. \& Southgate, D. A. T. (1978). McCance and Widdowson's The Composition of Foods, 4th revised ed. London: H. M. Stationery Office.

Prosky, L., Asp, N.-G., Furda, I., Devries, J. W., Schweizer, T. F. \& Harland, B. F. (1984). Determination of total dietary fibre in foods, food products and total diets: interlaboratory study. Journal of the Association of Official Analytical Chemists 67, 1044-1051.

Ranhotra, G. S., Gelroth, J. A. \& Bright, P. H. (1988). Effect of the source of fiber in bread on intestinal responses and nutrient digestibilities. Cereal Chemistry 65, 9-12.

Reddy, N. R., Pierson, M. D., Sathe, S. K. \& Salunkhe, D. K. (1984). Chemical, nutritional and physiological aspects of dry bean carbohydrates - a review. Food Chemistry 13, 25-68.

Rémésy, C. \& Demigné, C. (1989). Specific effects of fermentable carbohydrates on blood urea flux and ammonia absorption in the rat cecum. Journal of Nutrition $119,560-565$.

Ruppin, H., Bar-Meir, S., Soergel, K. H. \& Schmitt, M. G. (1980). Absorption of SCFA by the colon. Gastroenterology 78, 1500-1507.

Russell, J. B. \& Hespell, R. B. (1981). Microbial rumen fermentation. Journal of Dairy Science 64, 1153-1169.

Seal, J. C. \& Mathers, J. C. (1989). Intestinal zinc transfer by everted gut sacs from rats given diets containing different amounts and types of dietary fibre. British Journal of Nutrition 62, 151-163.

Shutler, S. M., Bircher, G. M., Tredger, J. A., Morgan, L. M., Walker, A. F. \& Low, A. G. (1989). The effect of daily baked bean (Phaseolus vulgaris) consumption on plasma lipid levels of young normo-cholesterolaemic men. British Journal of Nutrition 61, 257-265.

Shutler, S. M., Walker, A. F. \& Low, A. G. (1987a). The cholesterol-lowering effects of legumes. 1. Effects of the major nutrients. Human Nutrition: Food Science and Nutrition 41F, $71-86$.

Shutler, S. M., Walker, A. F. \& Low, A. G. (1987b). The cholesterol-lowering effects of legumes. 2. Effects of fibre, sterols, saponins and isoflavones. Human Nutrition: Food Science and Nutrition 41F, 87-102.

Skurpakkar, K. S., Sundaravalli, O. E. \& Rao, M. N. (1979). In vitro and in vivo digestibility of legume carbohydrates. Nutrition Reports International 19, 111-117.

Southgate, D. A. T., Branch, W. J., Hill, M. J., Drasar, B. S., Walters, R. L., Davies, P. S. \& McLean Baird, I. (1976). Metabolic responses to dietary supplements of bran. Metabolism 25, 1129-1135.

Stephen, A. M. \& Cummings, J. H. (1980). Mechanism of action of dietary fibre in the human colon. Nature 284, 283-284.

Stephen, A. M., Wiggins, H. S., Englyst, H. N., Cole, T. J., Wayman, B. J. \& Cummings, J. H. (1986). The effect of age, sex and level of intake of dietary fibre from wheat on large-bowel function in thirty healthy subjects. British Joumal of Nutrition 56, 349-361.

Thompson, A. (1970). Rat metabolism cage. Journal of the Institute of Animal Technicians 21, 12-21.

Tobin, G. \& Carpenter, K. J. (1978). The nutritional value of the dry bean (Phaseolus vulgaris) : a literature review. Nutrition Abstracts and Reviews 48A, 919-936.

Tulung, B., Rémésy, C. \& Demigné, C. (1987). Specific effects of guar gum or gum arabic on adaptation of caecal digestion to high fiber diets in the rat. Journal of Nutrition 117, 1556-1561.

Van Dokkum, W., Pikaar, N. A. \& Thissen, J. T. N. M. (1983). Physiological effects of fibre-rich types of bread. 2. Dietary fibre from bread: digestibility by the intestinal microflora and water-holding capacity in the colon of human subjects. British Journal of Nutrition 50, 61-74.

Van Soest, P. J. \& Wine, R. H. (1967). Use of detergents in the analysis of fibrous feeds. IV. Determination of cell wall constituents. Journal of the Association of Official Analytical Chemists 50, 50-55.

Wilder, B. M. \& Albersheim, 1. (1973). The structure of plant cell walls. IV. A structural comparison of the wall hemicellulose of cell suspension cultures of sycamore (Acer pseudoplatanus) and of red kidney bean (Phaseolus vulgaris). Plant Physiology 51, 889-893.

Wyatt, G. M., Horn, N., Gee, J. M. \& Johnson, I.T. (1988). Intestinal microflora and gastrointestinal adaptation in the rat in response to non-digestible dietary polysaccharides. British Journal of Nutrition 60, 197-207.

Zar, J. H. (1974). Biostatistical Analysis, p. 257. Englewood Cliffs, N.J.: Prentice-Hall. 